\title{
Fostering Innovative and Entrepreneurial Talents of Packaging Engineering Based on Curriculum Construction
}

\author{
Yucong Zhao, Yong Ding, Manru Chen, Guozhi Li, Baohui Wu, Guifen Gong \\ Departmen of Packaging,College of Art and Design, Shaanxi University of Science \& Technology, \\ Xi'An, 710021, China \\ e-mail: zhaoyucong@sust.edu.cn
}

Keywords: Curricula Construction; Application-oriented Talents; Knowledge-transference

\begin{abstract}
It is an important target that high quality application-oriented talents with self-employed consciousness and innovation ability are trained via promoting quality-oriented education. Hence, the study serves curricula construction as the platform, sets up scientific and reasonable curriculum system, strengthens practical teaching contents and reforms teaching methods on the basis of professional features. Consequently, the transform from attention of knowledge-transference to emphasis on ability training is achieved, in the meantime, innovative and entrepreneurial capacities of packaging talents are improved.
\end{abstract}

\section{Introduction}

Personnel training mode of packaging engineering need to meet China's economic and social development, and satisfy with market requirement. Meanwhile according to school orientation, the needs of packaging industry development and the principle of "broad-caliber, solid foundation, strong competence and distinctive features", the comprehensive qualities of professional students need to be trained and promoted. Thus, innovative and entrepreneurial capacities of packaging talents are trained through transforming attention of knowledge-transference to emphasis on ability training, which is performed in light of requirement, "advanced ideas, goal-oriented, leading reform, qualified teachers, teaching excellence, well-equipped", and characteristics, demand and trends of current packaging industry and market[1]. As packaging engineering is a comprehensive and cross discipline, so the teaching reform goal of packaging engineering major in shaanxi university of science and technology is training of high-quality practical talents which have self-employed consciousness and innovation ability. This reform is base on conception framework which dues equal attention to both theory teaching and practical teaching. There are many achievements has achieved: provincial level teaching team (professional teaching team of packaging engineering, 2007), state-level characteristic disciplines (packaging engineering, 2010), shaanxi province famous-brand speciality (2006).

\section{Reform of personnel training mode}

A. Construction of Curriculum System

In accordance with cultivation conception of the inter-disciplinary talents of packaging engineering, curriculum structure need to be improved, course content need to be optimized and curriculum system need to be strengthened. Curriculum system includes common courses, specialized courses and optional courses, therefore professional main courses of packaging engineering are priority, optional modules of interdisciplinary course (such as logistical packaging, package printing, decoration design of packaging, e-commerce, etc.) are complementary, at the same time, basic theoretical courses and practical training need also to be strengthened[2].

The purpose of common courses is that guides students to develop well personality quality. In the education stage of common courses, some curricula and lectures have been added, such as science, culture, art, citizens and state, laws, career planning, military theory and so on. Those courses can develop students' high sense of social responsibility, open mind attitude, the spirit of rational criticism and strength of character quality, etc. In brief, the starting point of innovation must 
be based on the service of national progress, the development of the country and the overall interests of human society, so the setting of common courses can guide students become a qualified, high morality and broad interest citizen.

The key point of the reform of curriculum system is merging, integration of original specialized courses and professional basic course in order to learn to meet practical needs. On one hand, the professional core courses are determined by production practice, social development needs, and fully absorbing professional course essence of foreign first-class university. On the other hand, the optional courses are determined by fully investigating and surveying on employer and industry sector. This has advantage to fuse interdisciplinary and form the course system of broad-caliber and solid foundation. Some courses, such as engineering materials, finite element analysis method, foundation of control engineering, complex function and integral transform have been added. Similarly, the optional courses, specialized courses laws and regulations of packaging management, corrugated carton forming and printing, packaging and environment, etc, have been added in specialized courses. Those achievements update and perfect the curriculum system.

In the aspect of teaching material construction, teachers take participate in the third set of unified compiled teaching materials, investigate and survey packaging enterprises, as well as construct practical teaching system. There are two ways have been adopted as follows[3]:

Teaching material compilation: the new unified teaching materials have been compiled to meet with training programs and the adjustment of curriculum system which avoid overlapping of content.

Selection of teaching textbooks: Teaching materials of "12th five-year plan" Development Programming which were published in recent years and English original textbooks were introduced to satisfy with the quality education and ability training. In the meantime, the ratio of bilingual teaching has reached more than 20\%, and the teaching effect has made a considerable progress. Digital resource centre, which makes use of online education resources and sharing platform, has been constructed to realize high quality resource-sharing.

B. Construction of Practice Teaching Mode

Through aiming at the international frontier fields, following the trend of industrial development and making full use of the school-enterprise cooperation, practical teaching platform and scientific research platform of on and off campus have been constructed[4].

1) Enhance practice teaching system in school: Experimental system adapting to talent training scheme has been established and perfected a solid hardware foundation so that students can conduct engineering skills training on campus. Through electronic practice, metalworking practice, production practice and graduation practice, it can strengthen students' ability to solve practical production problems, and improve students' innovation ability and application ability step by step. Furthermore, We have built advanced laboratory in China northwest region, such as flexible packaging and transport packaging test laboratory, packaging technology and equipment laboratory, packaging structure design laboratory, packaging printing laboratory, screen printing laboratory, packaging design research center and so on, meantime, have added mechanics and materials comprehensive experiment, mechanical foundation experiment, flexible packaging materials comprehensive experiment, etc. Engineering design comprehensive experiments have been added in curriculum design, therefore students' practical ability and innovation ability effectively were increased.

2) Construction of practice base off-campus and summer term social practice base: According to characteristics of packaging industry, the practice process includes designated practice and visit practice. The obvious advantage of this practice mode is that students not only can participate in the actual operation, but also can expand their horizon, get in touch with all kinds of packaging technology and packaging equipment.

3) Mutual complementation of theory teaching and practice teaching: Guided by the outstanding engineers training plan, practical teaching period has increased, and classroom teaching period has been appropriately cut. The practice teaching in school must be ensured no less than half a year, and enterprise practice teaching time will reach more than six months. 
4) Regulation of practice teaching process: Making rational rules and regulations, it can guarantee the implementation of the practical teaching link. Firstly, laboratory opening rules is perfected. Furthermore, practical teaching links, such as curriculum instruction, time, lab report, appraisal etc., are improved. At last, graduation design topic must be derived from the requirements of production practice, and student evaluation mechanism is set up involved in school, employers and related departments.

C. Reform of Teaching Method

There are many problems of traditional teaching mode as follows[5]:

The chief method of classroom teaching is one-way communication. Teachers are responsible for teaching, and students only for listening and taking notes. They lack of interaction, and this teaching mode emphasizes on the memory of knowledge and repetitive practice.

Teaching evaluation system is relatively simple, test score is unique standard to evaluate students basically. But the score can not reflect well flexible mastering and practice ability of the students on professional knowledge, thus it can appear the phenomenon, that is so-called "high scores and low-abilities".

Owing to a lack of competition and cooperation between teachers, Applications of curriculum teaching methods are usually individual behavior of teachers, and good teaching method can't promote quickly. Many teachers are reluctant to improve teaching methods, and use outdated teaching materials and teaching methods in the long term. As a result, it is difficult that arouses learning motivation under the information era.

Teaching materials update slowly, and the contents of a great many teaching materials lag behind technical level that has been adopted in enterprises.

In order to develop students with innovative and entrepreneurial qualification, it is important for teachers to arouse the students' hobbies and interests. Since class teaching is first place of students' studying, so teaching method and leadership of teachers plays a particularly important role on studying process. We set up effective mechanism of fair competition and elimination mechanism, enhance cultivation of teaching ability of young and middle-aged teachers, improve teachers' education background[6].

1) Teaching methods and means: We pay attention to guide students to inquiry-based learning and investigative study, take the students as the main body of education, and use modern education technology to conduct teaching activities[7].

Teaching system that combines traditional teaching with online education and multimedia teaching, we make full use of modern teaching means and construct sharing platform of professional teaching resources database.

2) Teaching team: Due to packaging engineering belong to the inter-discipline, so it needs higher requirements for teachers' practice ability. We put forward the policy of "go out, invite in", create opportunities and send teachers to further study in colleges and universities at home or abroad.

3) Curriculum reform and cultivation: We enhance construction of national high-quality curriculum, implement $90 \%$ of the total number of professional courses to use multimedia teaching[8].

\section{Conclusion}

Enrichment, improvement and optimization of personnel training mode, curriculum system and teaching approaches improve greatly professional level and practice ability of the graduates. At the same time, we established a long-term cooperation relationship with some famous enterprises, such as Haier group, Huawei, ZTE, Foxconn, Zhejiang Stone Ltd, etc., and maintained stably united training mode.

In recent years, a higher requirement was put forward in colleges that innovative and entrepreneurial talents need to be trained. The perfect training plan is a necessary for high quality talents[9]. It is an effective way to promote the discipline construction and personnel training that focus on major characteristic, constructs knowledge system which meets the needs of society[10]. (See Fig.1) 


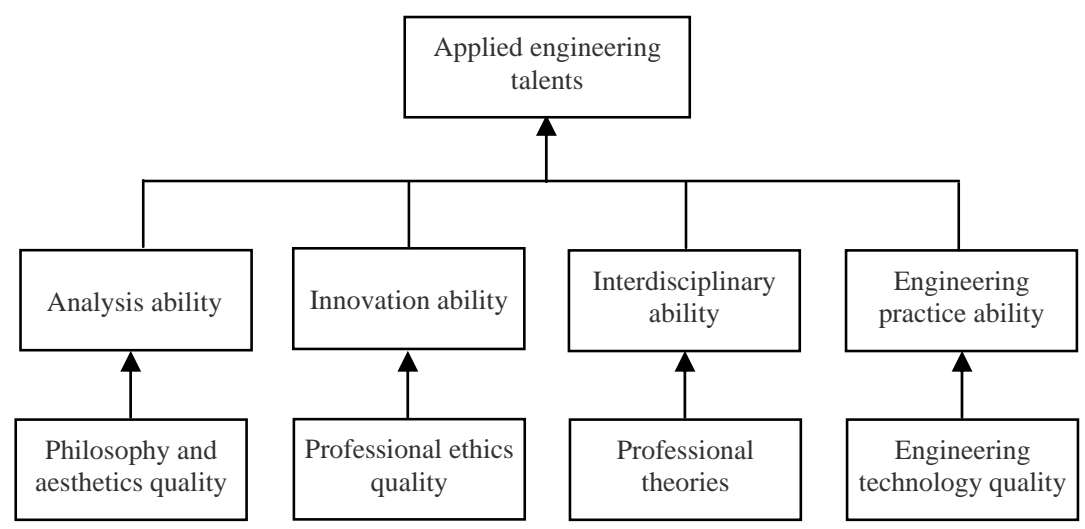

Fig.1 The Framework of character, ability and knowledge of applied engineering talents

\section{Acknowledgement}

The authors wish to express gratitude to members of Shaanxi provincial-level teaching team of packaging engineering, and also thank national-level bilingual teaching demonstration course of packaging technology to subsidize. Also, a special thank to Education Department of Shaanxi Provincial Government for the project funded (No.11BY32).

\section{References}

[1] Ministry of Education: The notification about starting construction of teaching quality and teaching reform engineering in higher school. [Z]. [2003]1,2003-04-08.

[2] Nathaniel Lasry, Eric Mazur, Jessica Watkins, Peer instruction: From Harvard to the two-year college, Am. J. Phys, vol. 76. 2008(11), p.1066-1069.

[3] F.H. Gong, L. Wang: On university exquisite course construction. Heilongjiang Researches on Higher Education, (2004) No.1, p.126.

[4] Q.Q. Zhong, H.H. Luo: Course Paradigm Shift: Shanghai and Hong Kong's Curriculum Reform. Shanghai Scientific and Technological Educational Publishing House, China 2003, p.15.

[5] C. Liu: The mission of the university in a learning society. Adult Education, (2004) No.5, p.11.

[6] G.F. Jiang, C.C. Guo: Discussion of college organic chemistry experiment teaching. Higher Education in Chemical Engineering, Vol. 97 (2009) No.5, p.42.

[7] Y.L. Xu, X.H. Zhao: Teaching reform base on the national excellent course medical statistics network platform. China Journal of Modern Medicine, Vol. 20 (2010) No.11, p.1749.

[8] X.F. Xu: Nonstandard and the standard on inquiry learning. Education Journal, (2009) No.2, p.21.

[9] Lin hua, Through construction of "curriculum group" to promot the cultivation of the innovative entrepreneurial talent, China Adult Education, vol. 12. 2008, pp.124-125.

[10] ZhaoYucong, Ding Yong, Application of peer-instruction pedagogy in curriculum of packaging technology (2011) International on Engineering Education and Management, 2011.12. 